\title{
Bruno Latour, Waar kunnen we landen? Politieke oriëntatie in het Nieuwe Klimaat-regime
}

\author{
Irawan Sewandono
}

Bruno Latour, Waar kunnen we landen? Politieke oriëntatie in het Nieuwe Klimaatregime. Vertaling Rokus Hofstede (Amsterdam: Octavo, 2018), 131 p.

Als jongeling heeft Bruno Latour gesmuld van bevlogen en met natuur en milieu in de Derde Wereld betrokken schrijvers als Romain Gary (Education européenne en Les racines du ciel) en natuurlijk ook Antoine de Saint-Exépury (Le petit prince). $\mathrm{Hij}$ is een toegangspoort tot de Zuid-Europese gedachtewereld en kan ons meer Angelsaksische wereldbeeld helpen corrigeren. Zijn breedsprakigheid en beeldspraak moeten we maar voor lief nemen. De titel van het pamflet verwijst naar het door hem geschetste beeld van passagiers in een vliegtuig opgestegen op weg naar het Globale, die te horen krijgen dat de piloot rechtsomkeert moet maken omdat hij niet meer kan landen op het vliegveld van bestemming, en die vervolgens moeten vernemen dat de noodlandingsbaan, het Lokale, eveneens ontoegankelijk is (p. 43-44, hoofdletters van Latour zelf).

Met Waar kunnen we landen? mengt Latour zich in het debat over de verandering van het klimaat en de eindigheid van natuurlijke hulpbronnen. Wat is het geëigende politieke forum voor beslissingen over verdrogende akkers en verdwijnende bossen, krimpende gletsjers en overstromende rivieren, energietransitie en CO2-opslag? Hij verdenkt de superrijken ervan te complotteren nu zij worden geconfronteerd met de klimaatcrisis. Zij geloven niet meer hun weelde tot het einde der jaren te kunnen delen, zelfs niet in beperkte mate, met de overige negen miljard mensen. Zij zijn niet van plan voor de kosten van de veranderingen op te draaien en willen die afwentelen op de overige bewoners van deze wereld. Hun kwaadaardige intenties verhullen zij door glashard de klimaatverandering te ontkennen. In zijn ogen verklaart dit de drie wereldwijde problemen van deze tijd: afbraak van de verzorgingsstaat, toenemende sociale ongelijkheid en ontkenning van de klimaatcrisis (p. 29).

Latour heeft een hartgrondige afkeer van binaire tegenstellingen. Hij zet eerst twee begrippen op een en dezelfde as als uitersten tegenover elkaar en gaat deze begrippen vervolgens tot op het bot ontleden zodat daarvan niet veel meer overblijft. Daarna poneert hij dat een nieuw begrippenpaar langs een andere as in het platte vlak in een geheel ander richting wijst, als het ware een vectorgrootheid is, en dus in zijn ogen wel veel relevanter moet zijn dan het aanvankelijk onderscheiden paar. Zo ontrafelt hij de begrippenparen Lokaal-Globaal (p. 41), vooruitgangachteruitgang (p. 47), oud-nieuw (p. 52), links-rechts (p. 60) en Modern-Aards (p. 65). Hij betoogt dat de groene politieke partijen niet passen in het traditionele stramien van links of rechts. De politieke kleur van hun standpunt(en) hangt 
telkens af van het onderwerp. Als het gaat om wateroverschotten of elektrische auto's zijn ze vooruitstrevend, als het gaat om haaglandschappen of nieuwe vliegvelden behoudend. Zij scharen zich nu eens achter links, dan weer achter rechts. Volgens Latour is hun grote verdienste dat zij onderwerpen op de politieke agenda hebben weten te zetten waarover de mensen zich tot dan toe in het openbare leven nog niet druk maakten (p. 58).

Een ander voorbeeld van zijn afkeer van binariteit is de enigszins oosterse visie van Latour op het onderscheid tussen mens en natuur. Zoals 'goed' ondenkbaar is zonder 'kwaad', zo zijn mens en natuur onlosmakelijk met elkaar verbonden. In eerder werk pleitte Latour al voor een meer symmetrische antropologie: er is geen scherpe grens tussen object en subject, tussen feiten in de natuur en de menselijk samenleving (Wij zijn nooit modern geweest [Amsterdam: Boom, 2016]). Vanaf de zeventiende eeuw heeft het antropocentrisme de overhand gekregen en zijn we modern geworden. In het Westen wordt de menselijke activiteit gezien als iets dat losstaat van de natuur: de natuur praat niet terug (p. 78-79). De natuurwetenschappelijke vaststelling van feiten is niet genoeg. Daarna moeten deze feiten nog worden vertaald in woorden om in het politieke debat hun weg te kunnen vinden.

Latour begeeft zich, na veel ontleden en relativeren, op ontdekkingsreis met Michael Polanyi en James Lovelock en gaat met hun ideeën aan de haal. Hij hoopt dat de emoties van socialisme en klassenstrijd zich verbinden met de kracht van ecologische bewegingen tot een geo-sociale plaatsenstrijd (p. 76). Hij ziet dat levende wezens actief betrokken zijn bij bio- en geochemische processen (p. 91). De Aarde bevat niet alleen maar hulpbronnen voor de productie van goederen. Gaia is een levend organisme, een systeem voor het verwekken van Aardbewoners. Dat zijn niet alleen mensen (p. 98).

In het voorlaatste hoofdstuk stelt Latour dat de belangen van de Aarde weliswaar bij iedereen bekend zijn, maar dat de behartiging ervan nog niet institutioneel is ingebed (p. 107). We moeten beginnen met te inventariseren wat iedere bewoner van de Aarde nodig heeft voor zijn voortbestaan en waarvoor hij bijgevolg bereid is te vechten. Door de mondialisering is aan de top het contact van de politiek met de grond verloren gegaan en zijn de mensen zich niet meer veilig gaan voelen. Dit kan alleen worden hersteld door weer van voren af aan te beginnen en iedere Aardbewoner opnieuw zijn levensterrein te laten definiëren (p. 110). Bestaan als volk en de eigen levensterreinen kunnen beschrijven is een en hetzelfde ding (p. 114).

In het slothoofdstuk komt de politieke aap uit de mouw: Latour koestert hoge verwachtingen van de Europese Unie. Deze juridische uitvinding is een reactie op het achterhaalde idee dat de natiestaat als enige bij machte is zijn volk te beschermen en zijn veiligheid te waarborgen (p. 117). Europa heeft op alle mogelijke manieren de nationale soevereiniteit, de grenzen en deugden ervan, aan elkaar gebreid en weer losgetornd. Het is klein genoeg om zich niet de gehele wereld te wanen en groot genoeg om zich niet tot een lapje grond te beperken (p. 122). 
Een bezoek aan de TEFAF-kunstbeurs in Maastricht heeft me ontvankelijk gemaakt voor de hypothese van Latour. De superrijken van vandaag zijn geen Don Fabrizio. Deze gewetensvolle aristocraat zag zich in 1860 op Sicilië, na de verjaging van de Bourbons en de Italiaanse eenwording, voor de vraag gesteld wat te veranderen om het goede te behouden. Hij dacht daarbij aan de armenzorg door de Kerk (Giuseppe Tomasi di Lampedusa, De tijgerkat).

De argumentatie van Latour kan mij daarentegen niet helemaal overtuigen. Kenmerkend voor de staat zijn drie elementen: grondgebied, bevolking en stabiele rechtsorde, kortom de natiestaat van de negentiende eeuw. Het is echter maar de vraag of het supranationale Europa principieel echt iets anders is dan een staat. De nationale grenzen van de lidstaten zijn slechts opgeschoven en vervangen door de even onwrikbare buitengrenzen van de Unie en onderdanen van derde landen hebben geen toegang tot de gemeenschappelijke markt en het vrije verkeer tussen de lidstaten. Voor zover de lidstaten hun soevereine rechten en bevoegdheden hebben overgedragen, worden ze nu uitgeoefend door de instellingen in Brussel. De Unie biedt dus vooral schaalvergroting. En daarmee zijn we ook beland bij het zwakke punt van het pamflet. Klimaatcrisis, circulaire economie en beteugeling van sociale ongelijkheid vragen om ingrepen van zeer uiteenlopende aard. In Brusselse termen gaat het om subsidiariteit. Nu eens betreffen het maatregelen op een schaal die de afzonderlijke staten ver te boven gaat, dan weer meer concrete oplossingen en kleinschalige uitvoering op het niveau van de lokale overheden.

Kijken we naar Nederland, dan staan de deuren al wijd open voor de woordvoerders van Gaia. Wie de weg weet in Den Haag, kan in een vroeg stadium opkomen voor haar belangen, praten met ambtenaren en bewindslieden, deelnemen aan rondetafelbijeenkomsten met politici, aan Kamerleden suggesties doen voor vragen en amendementen. Iedereen mag meedenken via internetconsultatie. Maar in het land van minderheden en coalities krijgt niemand altijd gelijk en moet elkeen water bij de wijn doen. Overigens hebben belangenorganisaties als Waddenzee, Natuurmonumenten en Urgenda al jarenlang toegang tot de Nederlandse rechter. Ook kan worden gewezen op de introductie van de figuur van de amicus curiae in de bestuursrechtspraak (Raad van State, Jaarverslag 2017, p. 70).

Het klimaatdebat raakt grond- en mensenrechten en wordt daarom ook uitgevochten in de rechtszaal. Ik wil hier kort twee zaken bespreken. Volgens het Hof Den Haag moet de Staat het leven van zijn burgers en hun woning beschermen. Dit geldt voor al zijn activiteiten, publieke of niet-publieke, die deze beschermde rechten in gevaar kunnen brengen. Zo nodig moet de Staat preventieve maatregelen nemen (ECLI:NL:GHDHA:2018:2591). Hiermee heeft deze Nederlandse rechter een zeer ruime interpretatie gegeven van het Europese Verdrag van de Rechten van de Mens, die ik zelf niet zo snel kan terugvinden in de Straatsburgse arresten. Het is maar de vraag of de Hoge Raad zich bij deze uitleg zal aansluiten. Ook op een ander front staat ons veel te wachten. Als beroep is ingesteld tegen een belastend besluit, kan de bestuursrechter de verbindendheid toetsen van de regeling waarop de bestreden beschikking berust. Voor het omgevingsrecht kan 
deze exceptieve toetsing van grote betekenis worden. De advocaat-generaal heeft hierover desgevraagd een lijvige en gedetailleerde conclusie genomen (ECLI:NL:RVS:2017:3557), strekkende tot afschaffing van de willekeursluis van het Landbouwvliegers-arrest (NJ 1987/251). Dergelijke geïntensiveerde toetsing ligt in ons land politiek zeer gevoelig en kan grote gevolgen hebben voor de machtenscheiding. De Afdeling bestuursrechtspraak heeft hierover prejudiciële vragen gesteld aan het Hof van Justitie van de EU (ECLI:NL:RVS:2019:260). Voor het Nederlandse recht is de verdienste van dit pamflet dat Latour een politiek-filosofische onderbouwing geeft voor de beide aanstaande eindbeslissingen van onze twee hoogste rechters. 